\title{
Teachers and public engagement: An argument for rethinking teacher professionalism to challenge deficit discourses in the public sphere
}

\author{
Sue Thomas* \\ Griffith University, Australia
}

\begin{abstract}
In the context of public debates on teacher quality, both media and education policy texts construct deficit discourses about teachers, discourses that work together to inform public, commonsense understandings of teacher quality. This paper explores the interrelationships between discourses on teachers constructed on television and in policies in the Australian policy context. Critical discourse analysis was employed to trace the links between the discourses on teachers constructed in a television situation comedy and discourses in the policy documents that inform the Australian Government Quality Teacher Programme. The paper demonstrates the interdiscursivity of media and policy discourses on teacher quality by analysing the ways that the television sitcom constructed a particular version of teachers within the quality policy context. The analysis highlights the need for teachers to challenge these deficit discourses. The paper concludes by arguing for a rethinking of teacher professionalism in ways that include active engagement in public debates on education.
\end{abstract}

Key words: media, policy, discourse, quality, teacher professionalism, public engagement

\section{Introduction}

In the last decade, public debates about teacher quality have been prominent in the Australian media. At the same time, government education policy has focused on teacher quality, a focus that saw the introduction of the Australian Government Quality Teacher Programme (AGQTP) (Australian Government Department of Education, 2005; DEST, 2003; DEETYA, 2000). This paper examines both media and education policy texts to show how these texts construct deficit discourses about teachers. Such discourses work together within the public sphere to privilege authoritative public discourses on teachers and teacher quality. The paper investigates one instance that demonstrates the interdiscursive connections between public discourses on teacher quality by analysing policy and media discourses.

\footnotetext{
* School of Education \& Professional Studies (Logan), Faculty of Education, Griffith University, Mt Gravatt campus, 176 Messines Ridge Road, Mt Gravatt, Queensland, 4122. Email: s.thomas@griffith.edu.au
} 
The paper analyses the public discourses on teachers constructed in two policy documents that were generated during the AGQTP. It then analyses the ways that a television sitcom, Sit Down, Shut Up (Herbert, 2001), constructed a particular discourse about teachers. The sitcom was broadcast in early 2001, around the same time as the introduction of the AGQPT, which spanned the period 2000-03. Analysis shows how the different discourses and genres of media and policy texts worked together to construct authoritative, public commonsense discourses about teacher quality, in which teachers were positioned as lacking in the qualities expected of the good teacher and as needing to lift professional skills to improve educational standards.

First, a framework for understanding the interdiscursivity of media and policy texts is outlined and critical discourse analysis (CDA) is identified as a useful means for investigating such interdiscursivity. Next, the discourses on teachers constructed in the education policies underpinning the AGQTP are analysed and discourses of quality assurance and of quality improvement are described. Discourses about teachers in the television sitcom are traced in order to show how the sitcom privileges a commonsense discourse on teacher quality. Analysis illustrates the way in which the interdiscursivity of media and policy discourses work to privilege dominant, deficit discourses on teachers. Finally, the paper concludes with a discussion of how the teaching profession can construct alternative discourses on quality, discourses that work to reconstruct the teaching profession as an actively voice in public debates on education.

\section{Investigating media and education policy discourses}

Recent research into the interrelationships between media and education policy recognises that the $21^{\text {st }}$ century is a media-saturated world (Kellner \& Share, 2007) in which the media, notably television, is central to public life (Barker, 1999). Not only does television, including situation comedy, seek to entertain, but it also provides information and space for debate about schools and teachers (Nations Johnson \& Holm, 1994). Television, and other media, generate points of view that strengthen or undermine support for specific educational policies, practices, and ideologies (Anderson, 2007; Thomas, 2009). This power of the media is made evident also, as Gewirtz, Dickson and Power (2004) note, when governments court media to influence public support for education policy. There is a need, therefore, to investigate media and policy issues and the interrelationships between them (Gerstl-Pepin, 2007; Thomas, 2006; Thomson, 2004).

In this paper, media and educational policy texts are understood as discourses, that is, as social practices that represent social realities in particular ways, and construct particular social positions (Thomas, 2006). Such discourses are public discourses in that they are constructed in, and circulate within, the public sphere (Thomas, 2006). Critical Discourse Analysis is employed as the means for investigating the links between media and texts. Of particular interest here is the interdiscursive hybridity of texts (Fairclough, 2006), the complex and unconventional ways in which texts draw on orders of discourses 'by mixing different and conventionally incompatible discourses, genres or styles from the same order of discourse' (Fairclough, 2006, p. 32). Within the order of discourse, a hegemonic, commonsense version of the world (Allan, 1998; Luke, 1995/1996), is constructed through a process of naturalisation (Woodside-Jiron, 2004). The effect is the 
establishment of an 'authorial voice' that suppresses differences and masks the socially constructed nature of the discourse (Gardiner, 1992, p. 192). Using these understandings, the analysis shows how discourses on teacher quality constructed both in education policies and in the television program, Sit Down, Shut Up, work to construct a natural, commonsense discourses about teachers, which are established as authoritative, public discourses on teacher quality.

\section{The Australian government quality teacher programme}

In Australia, teacher quality is a strong focus of Australian government education policy, as evidenced by the introduction of the AGQTP. Established in 2000, the AGQTP emphasised the importance of teacher quality to effective schooling, and to increased performance and productivity of schools within a climate of national microeconomic reform. The AGQTP programme was outlined in two policies. The first policy, (introduced in 2000), was Teachers for the 21st Century: Making the Difference (DEETYA, 2000, hereafter Teachers for the 21st Century). The second policy, introduced three years later, was Australia's Teachers: Australia's Future - Advancing Innovation, Science, Technology and Mathematics (DEST, 2003, hereafter Australia's Teachers: Australia's Future).

Together these policies mapped out a national project that had two objectives: 'to update and improve teachers' skills and understanding in priority areas' and 'to enhance the status of teaching in government and non-government schools' (Australian Government Department of Education, 2005, p. 1). Two discourses on teacher quality could be traced in the two policies. However, each policy constructed a preferred discourse. The earlier policy, Teachers for the $21^{\text {st }}$ Century, outlined a program designed to

... improve teacher quality and increase the number of highly effective Australian schools in order to maximise student learning outcomes ... by lifting the quality of teaching through targeted professional development and enhancing professional standards. (DEETYA, 2000, pp. 3, 5, 13)

The policy constructed a preferred discourse on quality that linked poor teacher quality to low standards and student outcomes. It identified teachers as being both the cause of low standards in Australian schools and the means by which educational standards would be raised through the 'development of professional standards and related certification for teachers' (p. 17).

Professional standards were 'the means of improving the quality of teaching and enhancing the professional standing of teachers' (DEETYA, 2000, p. 17). Teachers were required to

... work together within their school communities to identify goals, define standards and expectations, review and refine teaching practices and prioritise areas for action and improvement. [Teachers were to] accept responsibility for assessing the impact of their teaching on student outcomes and report on and [were to be] accountable for these outcomes. (DEETYA, 2000, p. 11)

Professional standards were linked explicitly to student outcomes and to teacher accountability. However, teachers were depicted as needing external assistance to set 
professional standards. Indeed, professional standards were to be developed 'by working with and through the teaching profession' (p. 12) in 'a cooperative effort from the Commonwealth Government, State and Territory government and non-government education providers, schools, principals, professional associations and parents' (p. 12). That is, members of the teaching profession were not granted autonomy to develop standards and so determine the norms of professional practice that would lead to improved student outcomes. Rather this process was to be guided by government.

The first policy, then, constructed a discourse of quality assurance (Sachs, 2003) that worked to establish as true a situation of low standards in Australian schools where teachers lacked the skills and understandings demanded within the current educational context. The discourse positioned teachers as requiring external assistance to develop professional standards. It justified the development of standards in terms of public accountability and gave limited professional autonomy to teachers. Quality schooling was defined in terms of the regulation and control of teachers through the development of professional standards and related certification. It was a regulatory discourse of quality in which teachers were positioned as needing to improve their skills. The focus was on the attainment of standards that would lead to improved performance.

The second policy, Australia's Teachers: Australia's Future, constructed a discourse on the quality of teachers and schools that focused on innovation rather than on a lack of skills and the need for regulation through the introduction of professional standards. Quality schooling, seen as necessary to sustain innovation, was defined in terms of the renewal of cultures of continuous innovation. The policy, therefore, emphasised not the raising of standards, but the 'energising [of] schools for innovation' (DEST, 2003, p. 217). Teachers were positioned by this discourse as 'the key to mobilising schools for innovation' (DEST, 2003, p. xvii) and the discourse emphasised the role of standards in teacher development through professional learning.

The preferred discourse constructed in Australia's Teachers: Australia's Future promoted a developmental approach to standards in the context of teacher professional development, learning, and career advancement. The development of standards was identified as a means of making explicit the norms of professional practice to which students were entitled and to which the wider public had a legitimate right to be assured. This discourse advocated transparency regarding the social and professional expectations and obligations of teachers. As such, it was a discourse of quality improvement through standards (Sachs, 2003).

The discourses on teacher quality constructed in the education policies of the AGQTP both emphasised the development of professional standards. The first discourse was a discourse of quality assurance that emphasised using standards to improve performance. The second discourse was a discourse of quality improvement and focused on the need to introduce standards to reform the profession. While the two discourses can be distinguished on the basis of varying degrees of professional autonomy over the control and ownership of the development and monitoring of the standards, both discourses were concerned with the processes of improving teacher quality. That is, policy discourses in the AGQTP depicted teachers in a deficit way, but advocated using professional standards in different ways to address this deficit. Similarly, as the following analysis demonstrates, the television sitcom constructed a deficit discourse about 
teachers. However, this discourse assumed a shared commonsense, natural view that simplified and reduced the complexity surrounding the issue of teacher quality.

\section{Media discourses: Sit Down, Shut Up}

Television programs such as sitcoms are sites where public discourses constructed about teachers can be traced. The following analysis shows how media discourses on teachers were constructed in the television sitcom, Sit Down, Shut Up. The sitcom depicted life in a secondary school, Carpen Heights Secondary College. Episodes in Sit Down, Shut Up featured events such as parent-teacher nights, the school play, the camp, the fete, and the production of the school newspaper, all of which are common events in the everyday life of a secondary school. However, little was shown of pedagogy, classrooms, or the students. Rather the emphasis in each episode was placed on the teachers and their staff relations. In each episode the teachers' handling of the events, and their relationships with each other, were depicted negatively. Sit Down, Shut Up consistently constructed a discourse of derision (cf. Kenway, 1990; Pettigrew \& Maclure, 1997) about teachers that depicted them as socially and professionally incompetent. Throughout the entire 10 episodes, teachers were shown to be lacking in the professional qualities desired in good teachers. Teachers were depicted as professionally incompetent and lacking commitment to their work; as failing to gain respect from their students or from each other; as having little concern for, or faith in, their students; and as engaging in unethical behaviour.

\section{Trivialising professional competence and commitment}

In Sit Down Shut Up, teachers’ professional incompetence was most evident when shown running the school events featured in each episode. The teachers were depicted as ineffective and their work was trivialised. For example, in an episode featuring an Alcohol Awareness talk, one teacher, Stefan, showed a film, Jurassic Park, which was totally unrelated to the topic. This theme was repeated again in another episode when Stefan showed the same video in an English literature lesson on Jane Austin's Pride and Prejudice. At the same Alcohol Awareness talk, yet another teacher, Stewart, began his section as follows:

Now I want you to pair off and talk about the five things that you most like about drinking alcohol. I'll give you a little head start. It's the only way to really connect and have a good time with your mates.

Stewart then proceeded to talk for three hours without saying anything negative about alcohol, thereby defeating the purpose of the Alcohol Awareness talk.

Teachers' professional incompetence in the area of curriculum development was trivialised also. While little attention was given to the school curriculum, one episode did address the issue of a relevant curriculum. That episode focused on the issue of girls' education and trivialised both the issue and the teachers' handling of it. First raised in a staff meeting, Sue, the acting principal, noted that large numbers of girls were leaving the school. As the following extract shows, two contradictory reasons were given for the 
exodus. One of these two reasons, offered by Julia, was educational. The other, offered by Sue was sexual.

Julia: Well I think the problem is educational. We actively discourage the girls from doing Science and Maths and push them into poise and correct posture classes.

Sue: $\quad$ No. I think it's got more to do with the fact there are no real lookers amongst the male staff members.

The remainder of the episode then explored the tensions between these two reasons. Julia believed that the girls were leaving because they were 'insulted by the subjects offered and the school's chauvinistic approach. Even our toilets are labelled men and non-men'. Sue, on the other hand, blamed the lack of 'male eye-candy'. She emphasised the importance of having 'a staff member who is, if you'll pardon the expression, a bit of a hornbag'. To her, changing the curriculum was a peripheral matter. The solution was to be found in obtaining a sexually attractive male teacher and Stefan, the most overtly sexual male teacher on staff, was told to 'lift his game'. As the episode unfolded, Julia's attempts at changing the curriculum led to divisions amongst the staff, divisions that were resolved only when Stefan recovered his sex appeal. Sue's actions were vindicated and teachers' professional knowledge about the curriculum was trivialised.

The sitcom also trivialised the teachers' commitment to their work. In particular, Stefan was depicted as not being dedicated. His lack of commitment to teaching was evidenced in his failing to prepare or to teach adequately, in his sending students home, and in his leaving school early. Stefan's lack of commitment is best demonstrated in an episode where he was asked why he was wearing a cycling suit by the acting principal. Stefan responded that he put on his suit in the lunch hour so he could be on his bike at ten past three, 'the end of the day'. His response indicated that he did not know that the school day ended at three thirty. Further, Stefan was unconcerned about this lack of commitment to his work, placing more emphasis on his sexual conquests. In all episodes, Stefan was represented as a teacher who likes 'to get out of here as quick as the next man', exhibiting a total lack of commitment to his work and to the students.

\section{Lacking respect, losing control}

In representing teachers as a professional group lacking in commitment, the series also depicted teachers as lacking respect. The teachers at Carpen Heights failed to gain respect both from their students and from their colleagues. Indeed, lack of respect is a theme repeated throughout the series. In one episode, the acting principal, Sue, noted in a staff meeting that 'it has become clear to me that certain members of the staff have lost the respect of the students'. Teachers were shown to be concerned about losing respect from their students because it indicated that they were losing control. Some teachers, for example. Felix, sought help from Dean, the Sports teacher, who gave often contradictory advice, none of which was in accordance with best teaching practice. For example in an episode that focused on behaviour management practices, Felix noted that 'the school students have absolutely no respect for me at all' and pointed out that when Dean yelled at them 'they scamper like school students'. He asked Dean to teach him how to yell. 
Dean advised Felix that 'good teachers don't need to yell. All they need to do is glare. I have given glares that have made students vomit’. Unfortunately, Felix’s attempts at glares led to him being charged with the sexual harassment of a student.

In another episode, Stewart approached Dean for advice as he felt that the students no longer looked up to him. Dean's response, as shown below, was to harangue the students in a way that demeaned both the students and himself.

Well if you want to know how to hang on to it [the idolisation of students], Stew, watch me work this room. Right, now everyone. Now today we are going down to the oval to play cricket. Now cricket if played right is a test of manhood. Now I still remember the first time I hit my father in the head with a cricket ball. He cried like a girl! I couldn't respect him after that. Just like you're not respecting me now Peter Luno! How dare you cross your arms when I'm talking to you! You may as well spit in my face! I have a good mind to walk over there, pick you up and knock you on your arse. Get out! Now does anyone else want to spit in my face? Try me punks.

Earlier Stewart had berated the students of the Drama teacher, Brent, for not showing respect. He interrupted Brent's classes several times in the mistaken belief that Brent needed help in controlling the class. Ironically, Brent was one teacher who had the respect of his students. Stewart's reaction to what he observed in Brent's classroom revealed his own prejudices and ignorance of Drama rather than an attempt to reassert teacher authority in the face of student disrespect. On his first intrusion into Brent's drama studio, Stewart asked students to

... give Mr Townsend-Ross a chance. Now I know Drama is a bludge subject, and if I was in your shoes I'd probably take the piss out of the guy as well. But you've got to see past his slight frame and feminine voice and quite frankly sexual ambiguity, and show some respect. OK mate! I'll let you get back to it. Don't let them worry you.

When later challenged by Brent, Stewart responded 'I could see they were walking all over you. And I know that you would do the same for me if I ever lost complete and utter control of my class'. After a second interruption of Brent's class, Stewart tells Sue, the acting principal, that 'those kids are just walking all over his face'. Stewart's concern in this episode seemed to be more about Brent's lack of control than about the students' lack of respect as his attempts to remedy the situation involved him demeaning and belittling a fellow staff member. Indeed, throughout the 10 episodes in the series, the teachers are depicted as having little concern for either each other or for the students.

\section{Faith in students and unethical behaviour}

Teachers' attitudes to the students depicted in Sit Down Shut Up ranged from irritation towards them to concern about costs of providing educational support. The most telling episode depicting teachers' attitudes towards students was the episode dealing with the school magazine. Julia, the young and enthusiastic Social Science teacher, was appointed editor of the school magazine. When she announced that the students would produce the magazine, she was greeted by scepticism from other staff members. She challenged this view of students by saying 'if we put a little faith in them I'm sure they will respond'. 
However as the deadline to publication gets closer, Julia had little response from the students. She told her class 'now, listen to me. You are all creative, intelligent human beings and this is your chance to prove it you moronic little bastards'. Sadly, there were no student contributions and despite announcing that 'the latest issue of the Carpen Heights school magazine is hot off the press and in keeping with my editorial policy, every single word is written by the students', Julia was later forced to admit 'it was me. I wrote every article'. This episode is telling in that it vindicated the other teachers' lack of faith in the students and that it showed Julia, the professional and dedicated teacher, engaging in unethical behaviour.

Unethical activity was depicted as usual behaviour for many staff at Carpen Heights Secondary College. Two teachers, Stefan and Stewart, were involved in stealing clothes. Another teacher, Felix, bribed some parents with a pass for their child in an exam, in order to gain a wide screen television to be raffled at the school fete. Such behaviour was either sanctioned or ignored by Sue, the acting principal. Sue was just as unethical in her demands that Helen, the school librarian, donate her furniture and the urn holding her mother's ashes to the White Elephant stall. However, Sue's most disturbing action was her agreeing to the trial of the use of steroids on a teacher, Stewart, without his knowledge or consent. She arranged with Dean to test the use of steroids on Stewart prior to their being used on students in order to improve their athletic achievements with a view to raising the school's sporting reputation.

The analysis of how teachers were depicted in the sitcom Sit Down, Shut Up shows that teachers were represented consistently as lacking the qualities expected in a good teacher. The teachers at Carpen Heights were depicted as lacking professional competence and commitment. They lacked the respect of their students and of each other. In addition, they lacked control of their students, for whom they had little concern and in whom they had no faith. Finally, they lacked ethics and were depicted as frequently engaging in unethical behaviour. The analysis has shown how the sitcom used aggressively cruel stereotyping of recognisable types (Selby \& Cowdry, 1995) to construct a media discourse of derision about teachers.

\section{Deficit discourses in the public sphere}

The media discourse on teachers described above echoes that identified in US television by Nations Johnson and Holm (1994), who found that most programs engaged in 'school bashing in which schools, teachers, and students were skewered, mocked or maligned in some way' (p. 252). There were instances in Sit Down, Shut Up when teachers were shown to demonstrate positive qualities, which included maturity, dedication, and care for the students, evidenced by considering their needs before any physical distress felt by the teacher. However, frequently, these positive qualities were followed by negative qualities that worked to construct ambiguous messages about teachers. For example, in the school magazine episode, Julia challenges the rest of the staff to have faith in the students' capabilities but later, in frustration at the lack of student response, calls her class 'moronic little bastards'. In another episode, Julia and Stewart are discussing why they became teachers. Stewart's response, 'partly because deep down inside I knew that I wanted to help the children grow and partly because I knew that deep down inside I'd 
failed Year 12', reinforces commonsense perceptions that teachers themselves are failures of the system within which they teach. It also trivialises the satisfaction that many teachers find in helping students grow and learn.

The construction of ambiguous media messages about teachers is not unusual. In the US, Nations Johnson and Holm (1994) found pro-education ideas tacked on to stories containing contrary notions often resulted in ambiguous messages about schools and teachers. This ambiguity allows the creation of 'sizeable communities of meaning' (Halliday, Jansen, \& Schneider, 1992, p. 64) and makes pinning down the full meaning constructed through the discourse difficult. Ambiguous messages encapsulate the 'favoured wisdom' of society and arise from basic assumptions shared by members of a society (Gee, 1990; Halliday et al., 1992). As such, these messages come to seem 'inevitable', 'natural', 'normal', 'practical', 'common sense' (Gee, 1996, p. 86).

Further, the messages constructed about teachers were constrained, and naturalised, by the conventions of the sitcom genre itself. The generic conventions of a text, including television texts, work to restrict the audience's ability or inclination to read the text in alternative ways and thus lead to a regulation of the content (Kantor, Kantor, Kantor, Eaton, \& Kantor, 2001; Taylor \& Wills, 1999). Sitcoms, while having the potential for challenging commonsense views, also reinforce audience prejudices or expectations and replicate reinforce preferred discourses (Kantor et al., 2001; Selby \& Cowdry, 1995).

Similarly, Kantor et al. (2001) note that sitcoms offer too few solutions to educational problems or suggestions of formulas for change. Instead, teachers are most often objects of ridicule in sitcoms. Certainly this was the case in Sit Down, Shut Up, where the use of ambiguous messages about teachers combined with the generic structure of the sitcom to construct a commonsense discourse that categorised teachers in a negative, derisory way. Such a discourse indicated that teachers needed to lift their professional skills in order to raise educational standards. Further, the teachers' lack of social competence that was depicted throughout the series led the viewer to presuppose that teachers lacked both the ability and the commitment to do this by themselves, and so needed to be regulated through the establishment and monitoring of professional standards by some other body.

As noted earlier, Sit Down Shut Up was broadcast in the early stages of the AGQTP. At that time, education policies on teacher quality were constructing deficit discourses on teachers also. These discourses positioned teachers as lacking in skills and as needing external assistance to set professional standards that would raise these skills and so improve performance and/or reform the profession. While these discourses can be distinguished on the basis of varying degrees of professional autonomy over the control and ownership of the development and monitoring of the standards, both discourses were concerned with the processes of improving teacher quality. As such, they were congruent with that constructed in Sit Down Shut Up as traced in the above analysis.

Such discourses are not uncommon in other forms of media. For example, in 2006, in the latter stages of the AGQTP, a similar discourse was constructed in the national newspaper, The Australian. In a series of items published through that year, the newspaper constructed a common sense discourse on teacher quality. Such a discourse evaluated teachers as untrustworthy; of a lower quality than teachers of previous generations; and as being responsible for falling standards in Australian schools (cf. 
Thomas, 2009). Thus, media and policy discourses worked interdiscursively to establish a perceived consensus on teachers as lacking both professional competence and the skill to raise professional standards themselves. Such a discourse is congruent with the discourses constructed in the policy documents of the AGQTP. Both the above analysis, and that of The Australian newspaper campaign, illustrates the ways in which the media act as a key site for education policy debate (Cohen, 2010). Both analyses trace discourses that call for external regulation of the teaching profession through standards.

\section{Reconstructing teachers as active participants in public debates on education}

The analysis outlined above highlights the difficulties facing Australian teachers in public debates over teacher quality. The interdiscursivity between public discourses demonstrated in this paper is not an argument for overdeterminism. Rather, it is an illustration of Rawolle's (2010) contention that media and education policy interact in an ongoing process of change. It illustrates also Cohen's (2010) findings that

... mainstream media cannot be dismissed as a site of public debate about education, but it must be engaged as only one of a number of possible sites, in conjunction with more attention to how teacher and teacher professional organizations can and do use alternative forms of public discourse (p. 117).

These findings support calls for teachers to be proactive in the construction of education discourses in public debates (Hodgens, Green, \& Luke, 1996) and to construct an active voice in debates on teacher quality and teacher professionalism (Australian College of Education, 2001; Ingvarson, 2001; Rust \& Meyers, 2006; Sachs, 2001). Thomas (2005, 2006) highlights the need for teachers themselves to construct alternative discourses on teacher quality.

How then can teachers construct such discourses and so reclaim an authoritative public voice in debates on education? Research (Anderson, 2007; Connell, 2009; Rust \& Meyers, 2006) offers suggestions for strategies that teachers can pursue in order to position themselves as critical stakeholders in education policy debates. Anderson (2007) suggests that teachers widen the frame within which an event is viewed by effectively disseminating knowledge and creating counterpolitical spectacles in order to influence how crises in education are defined. In addition, teachers can look at their own institutions in order to engage in authentic forms of change and in the construction of authentic selves. This latter strategy entails recognition of the diverse ways of being a good teacher and the development of a shared social identity of teaching within a lively occupational culture (Connell, 2009).

The strategies require teachers to engage in ways to reconceptualise the profession at both the public and personal levels. Rust and Meyers (2006) describe how changes in personal and professional knowledge can develop political awareness and acumen to inform policy-making. However, they see also a need for research, focusing on classrooms and schools. Such research should tell stories from the field in order to engage policy-makers in teachers' work. Public engagement with teachers' work is essential if the public discourses on teachers are to move from the focus on the personal found in Sit Down Shut Up to informed public understanding. As Rust and Meyers (2006) note, by 
engaging policy-makers with the public side of such research (and so teachers' work), negotiations of understandings about schools and teachers' work take place. During these negotiations, boundaries between spheres of influence are crossed and change happens.

The above strategies echo those found in the notion of teacher activism (Sachs, 2003; Yeatman, 1998), an idea useful when considering ways to reconstruct teaching as an authoritative, active voice in educational debates. Activism is defined by Yeatman (1998) as a publicly declared 'commitment, statement of vision, declaration of values and offerings of strategic action’ (p. 33). Similarly, Sachs (2003) notes that an activist teaching professional engages with, and responds to, issues that relate to education and schooling, reclaiming the professional agenda. Sachs further describes activist teaching professionals as: committed to a vision of schooling through a declared statement of values; socially critical and inclusive, working on democratic principles; future-oriented; responsive and responsible; strategic and tactical; creating an environment of trust and mutual support; engaging in collective and collaborative action; and acting with passion. Such a conception of the teaching profession requires teachers at all levels to rethink their professional identity. That is, teachers need to consider collectively how they define themselves, both in schools and in the wider community; in particular, to recognise the importance for public engagement in debates about schools and teachers. The tasks of reconceptualisation and engagement do not come easily to many teachers, but are essential if the teaching profession is to challenge the deficit discourses traced in the above analysis in order to frame future public agendas for schools and education, and so reestablish the teaching professional as a significant voice in public debates on education.

\section{References}

Allan, S. (1998). News from nowhere: Televisual news discourse and the construction of hegemony. In A. Bell \& P. Garrett (Eds.), Approaches to media discourse (pp. 105-141). Oxford: Blackwell Publishers.

Anderson, G.L. (2007). Media's impact on educational policies and practices: Political spectacle and social control. Peabody Journal of Education, 82(1), 103-120.

Australian College of Education. (2001, April). Teacher standards, quality and professionalism working document outcomes from a national professional summit. Paper presented at the National professional Summit on Teacher Standards, Quality and Professionalism, Canberra.

Australian Government Department of Education, Science and Training. (2005). An evaluation of the Australian Government Quality Teacher Programme 1999 to 2004. Canberra: Commonwealth of Australia.

Barker, C. (1999). Television, globalization and cultural identities. Buckingham: Open University Press.

Cohen, J.L. (2010). Teachers in the news: a critical analysis of one US newspaper's discourse on education, 2006-2007. Discourse: Studies in the Cultural Politics of Education, 31(1), 105-119.

Connell, R. (2009). Good teachers on dangerous ground: Towards a new view of teacher quality and professionalism. Critical Studies in Education, 50(3), 213-229.

Department of Education Science and Training. (DEST) (2003). Australia's Teachers: Australia's Future Advancing innovation, science, technology and mathematics. Retrieved 19 September, 2004, from http://dest.gov.au/schools/teachingreview/documents/Main-Report.pdf 
Department of Employment Education Training and Youth Affairs. (DEETYA) (2000). Teachers for the 21st Century: Making the difference. Canberra: Commonwealth of Australia.

Fairclough, N. (2006). Language and globalization. London: Routledge.

Gardiner, M. (1992). The dialogics of critique M.M. Bakhtin and the theory of ideology. London: Routledge.

Gee, J.P. (1990). Social linguistics and literacies: Ideology in discourses. London: The Falmer Press.

Gee, J.P. (1996). Social linguistics and literacies: Ideology in discourses (2nd ed.). London: Taylor \& Francis.

Gerstl-Pepin, C. (2007). Introduction to the special issue on the media, democracy, and the politics of education. Peabody Journal of Education, 82(1), 1-9.

Gewirtz, S., Dickson, M., \& Power, S. (2004). Unravelling a 'spun' policy: a case study of the constitutive role of 'spin' in the education policy process. Journal of Education Policy, 19(3), 321-342.

Halliday, J., Jansen, S.C., \& Schneider, J. (1992). Framing the crisis in Eastern Europe. In M. Raboy \& B. Dagenais (Eds.), Media, crisis and democracy mass communication and the disruption of social order (pp. 63-78). London: Sage Publications.

Herbert, P. (2001). Sit Down, Shut Up [Television series]: Channel 10.

Hodgens, J., Green, L., \& Luke, A. (1996). Literacy debates and professional strategy. Literacy Learning: Secondary Thoughts, 4(2), 10-18.

Ingvarson, L. (2001). Strengthening the profession? A comparison of recent reforms in the UK and the USA. Deakin West, ACT: The Australian College of Education.

Kantor, K., Kantor, N.L., Kantor, J., Eaton, M., \& Kantor, B. (2001). 'I will not expose the ignorance of the faculty’: The Simpsons as school satire. In P. Bolotin Joseph \& G.E. Burnaford (Eds.), Images of schoolteachers in America ( ${ }^{\text {nd }}$ ed., pp. 185-200). Mahwah, New Jersey: Lawrence Erblaum Associates.

Kellner, D., \& Share, J. (2007). Critical media literacy: Crucial policy choices for a twenty-first democracy. Policy Futures in Education, 5(1), 59-69.

Kenway, J. (1990). Education and the right's discursive politics. In S.J. Ball (Ed.), Foucault and education (pp. 167-207). London: Routledge.

Luke, A. (1995/1996). Text and discourse: An introduction to critical discourse analysis. In M.W. Apple (Ed.), Review of Research in Education 21, 1995-1996 (pp. 3-48). Washington, DC: American Educational Research Association.

Nations Johnson, L., \& Holm, G. (1994). Education 1st! Using television to promote the schools. In P. Farber, E.J. Provenzo, \& G. Holm (Eds.), Schooling in the light of popular culture (pp. 247-265). Albany, NJ: SUNY Press.

Pettigrew, M., \& Maclure, M. (1997). The press, public knowledge and the grant maintained schools policy. British Journal of Educational Studies, 45(4), 392-405.

Rawolle, S. (2010). Understanding the mediatisation of policy as practice. Critical Studies in Education, 51(1), 21-39.

Rust, F., \& Meyers, E. (2006). The bright side: teacher research in the context of educational reform and policy-making. Teachers and Teaching, 12(1), 69-86.

Sachs, J. (2001). Teacher professional identity: Competing discourses, competing outcomes. Journal of Education Policy, 16(2), 149-161.

Sachs, J. (2003). The activist teaching profession. Buckingham: Open University Press. 
Selby, K., \& Cowdry, R. (1995). How to study television. London: Macmillan.

Taylor, L., \& Wills, A. (1999). Media studies texts, institutions and audiences. Malden, Massachusetts: Blackwell Publishers.

Thomas, S. (2005). Taking teachers out of the equation: Constructions of teachers in recent education policy documents. Australian Education Researcher, 32(3), 45-62.

Thomas, S. (2006). Education policy in the media: Public discourses on education. Teneriffe: Post Pressed.

Thomas, S. (2009). Newspapers on education policy: constructing an authoritative public voice on education In R. Fitzgerald \& W. Housley (Eds.), Media, policy and interaction (pp. 205-223). London: Ashgate Publishing.

Thomson, P. (2004). Introduction. Journal of Education Policy, 19(3), 251-253.

Woodside-Jiron, H. (2004). Language, power, and participation: Using critical discourse analysis to make sense of policy. In R. Rogers (Ed.), An introduction to critical discourse analysis in education (pp. 173-205). Mahwah, New Jersey: Lawrence Erblaum Associates.

Yeatman, A. (Ed.). (1998). Activism and the policy process. St Leonards, NSW: Allen \& Unwin. 